\title{
THE QUESTION OF THE CONCEPTUAL DIFFERENCE BETWEEN REGULATORY AND PROTECTIVE CIVIL RELATIONS. TEMPORAL FACTORS
}

\section{Guyvan P. D.}

\section{INTRODUCTION}

Subjective substantive law in the process of its implementation simultaneously implements several general civil principles. Among them the most important of the inherent functions of civil law: regulatory and protective. Accordingly, regulatory and protection law are integral parts of legal law. Thus, relations mediated by substantive law may be regulatory or protective in nature, and regulatory and protective legal relations are interdependent and have a close relationship. Regulatory are the relations through which the order of correct, proper behavior of the subjects of civil relations is established, they are aimed at achieving a certain positive result ${ }^{1}$. Protective relations are aimed at protecting what has been achieved, they provide a legal opportunity to stop the violation of subjective law, eliminate the negative consequences of such a violation ${ }^{2}$.

Civil law relations of their participants may be carried out only on the basis of regulatory norms, if the activities of persons in the field of civil circulation are lawful. In other words, regulatory is a legal relationship under which the normal substantive and legal interaction of its participants. In fact, such a relationship is a legal relationship between the parties to civil relations, which is determined by the rules of civil law and is designed to ensure the realization of rights and responsibilities. The authority due to the authorized person is exercised by him / herself independently or by taking the necessary actions by the obligated entity. For example, under a contract, one party (the contractor) must perform certain work for the customer, and the latter must accept and pay for it. The activities of each of the parties to the agreement, if it takes place within the lawful conduct specified by law or contract, are mutually expected and therefore normal. But, despite the normal course of regulatory relations, their content includes certain requirements of the authorized person and the responsibilities of another. Such claims, which do not have a claim, are not subject to the statute of limitations. And the possibility of coercive measures provided for in the

\footnotetext{
1 Харитонов Є.О. Класифікація цивільних правовідносин: спроба новацій у підходах. Наукові праці Одеської національної юридичної академії. С. 138.

${ }^{2}$ Цивільне право України / за ред. О.В. Дзери, Н.С. Кузнєцової. Київ : Юрінком Iнтер, 2002. C. 85.
} 
agreement is abstract. Therefore, the probability of coercion has the form of only an objective possibility, so it is not part of the content of the regulatory relationship.

In scientific research, the relationship between regulatory and protective legal relations, in particular, regarding their temporal characteristics, has been covered in the works of numerous scholars. In these works, the study of the content of the relationship at the level of creditor - debtor in different states of interaction, including the phase of the offense and determining the legal status of counterparties. An analysis of the temporal component of a person's right to perform their own productive actions and demand the necessary behavior from the counterparty within the regulatory and protective relationship. However, the urgency of the issue remains significant. In particular, the description of regulatory and protective powers as a cause and effect proposed in the literature hardly deserves support ${ }^{3}$. Their interconnectedness, in fact, manifests itself in something else. The protection and legal relationship arises not as a result of the existence of the regulatory, but as a result of its violation by the obligated person. However, such a violation does not always occur, so not every regulatory right of a person is accompanied by the further emergence of his protection law.

\section{Review of scientific concepts on the essence of the material legal relationship}

The variety of obligatory property relations and the peculiarities of their course in time require a certain classification of civil law terms, which mediate certain relationships, determine the time of realization of the person's subjective right and fulfillment of legal obligation, which are part of the material obligation. knitting. This should take into account not only the temporal characteristics of the regulatory obligation, but also the protective, which arises after the violation of subjective law. The temporal characteristics of the existence and implementation of the protective powers of their bearer, including the substantive right to sue (claim) are very important and relevant. This provides an opportunity to properly assess the legal nature, meaning and place of time in the process of acquisition, implementation and protection of subjective civil rights.

The content of the regulatory civil legal relationship is a mechanism to ensure the ability of the entitled person to exercise their subjective rights and perform the legal obligations of the obligated person. However, one of the main features of civil law regulation is the method of protection of civil rights. This means that in the case of an offense, there is a legal protection of subjective rights, including through the use of coercion. It has been rightly noted in the literature that the sign of judicial protection is common not only

\footnotetext{
${ }^{3}$ Осокина Г.Л. Право на защиту в исковом судопроизводстве (право на иск). Томск : Изд-во Том. ун-та, 1990. С. 37.
} 
for civil rights, certain rights arising from labor, family, land, administrative relations can be protected in court. However, we repeat, for civil law relations (it would be more correct to say - for private law) the claim protection of the violated subjective right is general, while for other listed branches it is rather auxiliary.

The main problem of scientific study of the currently researched issues is that some issues remain not fully studied, so modern legislation does not provide a clear answer to some of the demands of real practice. Unfortunately, the scientific study of the content and timing of the protection of violated subjective rights of the individual is mainly reduced to the analysis of the emergence, implementation and termination of only one of the protective mechanisms - claims. Meanwhile, protective legal relations arising from the violation of the regulatory substantive law of a person may be implemented out of court. We must state that serious scientific research on the temporal features of this issue has not been conducted in the civil literature. From a methodological point of view, it is difficult to agree with this. This is largely due to an underestimation of the severity of the problem or even a lack of understanding of the importance of relevant civil relations. That is why, for example, for many years the mechanism of application of operative methods of influencing the offender was regulated by case law, which, in turn, quite carefully and often ambiguously reflected the application of such measures, including in the temporal dimension. Therefore, it is very important to study the general laws of the protective legal relationship from the moment of the offense to the time of the relevant measure of responsibility.

What actually happens to the regulatory relationship in case of its violation. There is no unity of scientists on this issue. According to the established tradition of the Soviet times, the protective property, ie the possibility of the right to be protected, is inherent in the very subjective law and is one of its inalienable powers. A similar approach was manifested in the pre-revolutionary period. Yes, Yu.S. Gambarov pointed out that the protection of civil law by its holder is an element of the structure of any subjective right. Its "formal moment" is realized in the form of a lawsuit, objection, application of permitted arbitrariness, etc. All these methods of protection are sanctions, without which the law can not do, but they should not be confused with the subjective right ${ }^{4}$. Soviet scholars also mostly adhered to a similar paradigm: M.A. Gurvich, S.M. Bratus, M.M. Agarkov, O.S. Ioffe, B.B. Cherepakhin and other authors postulate that after the violation of the material legal relationship is transformed, the subjective right passes into a state of maturity of the claim (claim), takes the form of a substantive right to sue. The basic principles of this theory were expressed most fully M.A. Hurwich: in the case of an offense, the subjective substantive law passes into the so-called "tense" state, ie the stage of the

\footnotetext{
${ }^{4}$ Гамбаров Ю.С. Гражданское право. Москва : АО «Центр ЮрИнфоР», 2003. С. 390.
} 
right to sue, the subjective right acquires the ability to enforce with the help of a state jurisdiction, and this is the essence of protection substantive law ${ }^{5}$. Thus, according to this doctrine, in addition to the power to own active actions of the right holder and the power to demand a certain action from the obligor, the subjective right also includes the possibility of protecting the right in case of violation by coercion ${ }^{6}$.

In this case, the possibility of protection of the violated right was understood as its enforcement ${ }^{7}$. In this regard, for the most part, there were no controversies among scientists. But then they arose and gained the level of serious discussions. Some believed that after the termination of the possibility of compulsory judicial protection, the protected right itself ceases ${ }^{8}$, others indicated the continuation of the existence of the latter, but already in a weakened (irrevocable) state without the ability to further its enforcement ${ }^{9}$. Proponents of the concept of the inalienability of the coercion of law argued that the loss of such a property automatically means the destruction of the law itself, which cannot exist without one of its essential features. Instead, scholars who argued for the transition of the right to a state of claim in case of its violation, mostly did not see the end of the statute of limitations a threat to the subjective right, believing that it now returns to the state of non-claim and thus continues to exist, forever deprived of the ability to enforce.

M.A. Gurvich notes that as a general rule, the transition of substantive law after the delay of its implementation in the right to sue is irreversible. It can no longer acquire a regulatory form. However, the author points to certain exceptions to this rule: it is a legislative act (moratorium) or an agreement of the parties to change the maturity of the law ${ }^{10}$. After the deadline, the subjective right must either be exercised or become a claim. It becomes violated, the statute of limitations for the relevant requirements begins. Any agreements on postponement of execution after the entitled person has the right to sue, according to Ukrainian civil law do not affect the statute of limitations, so the right continues to be in a state of coercion and can not return to non-claim (immature) state. In fact, from the standpoint of modern legal concepts, it is difficult to agree with such statements, even if we positively perceive the currently commented general concept. And yet let us consider in more detail the theory that has so long dominated civilization.

\footnotetext{
${ }^{5}$ Гурвич. М.А. Право на иск / отв. ред. : Клейнман А.Ф. Москва - Ленинград : Изд-во АН СССР, 1949. С. 145.

6 Грибанов В.П. Право на защиту как одно из правомочий субъективного гражданского права. Вестник МГУ. Серия ХІІ. Право. 1968. № 3. С. 23.

${ }^{7}$ Unger, J. System des jsterreichischen allgemeinen Privatrechts / Bd. I, 2 Aulf. Leipzig, 1892. Bd. 2. S. 354.

${ }_{9}^{8}$ Иоффе О.С. Советское гражданское право. Москва : Юрид. лит., 1967. С. 352.

${ }^{9}$ Новицкий И.Б. Сделки. Исковая давность. Москва : Госюриздат, 1954. С. 224.

${ }^{10}$ Гурвич М.А. Право на иск / отв. ред. : Клейнман А.Ф. Москва - Лениград : Изд-во АН СССР, 1949. С. 161.
} 
The basis for the emergence of a "tense" state of subjective substantive law (its ability to enforce) was considered a certain legal fact - an offense. In short, the legal purpose of legal facts is reflected in the current version of Article 11 of the CCU: they are the grounds for the emergence, change or termination of civil rights and obligations. It is in this context that legal facts have been and are being considered in our civilization. It is believed that actions take place in accordance with the will of the participants in civil relations, the events outside and regardless of the will of these persons. In turn, actions can also be differentiated as transactions and offenses. This thesis, if further developed, inevitably leads to the conclusion that the offense as a legal fact is important for the emergence of a coercive property of subjective law. In some cases, it will be sufficient for the entry into force of the subjective right of a person to protection, in others - the offense is part of the actual composition, the formation of which entails this consequence. Thus, the overdue monetary obligation of the debtor creates a protective power of the creditor within the scope of the obligation, which arises from the time for payment. On the other hand, the claim against the carrier in international transportation arises after the formation of the actual composition, which in addition to the offense also includes the active claim of the commissioner and the passivity of the debtor within the specified time limits.

Thus, according to the commented theory, the facts that cause the maturity of the claim are the circumstances associated with the occurrence of the conditions and term of the material claim. In particular, the omission of the term of performance of the obligation gives the subjective right a coercive property and the continued existence of such a right automatically means its violation by the obligated person. After the expiration of the term, the substantive right is either terminated as a result of its implementation, or continues to exist in a violated state. In the latter case, it receives a claim. Finally, it is emphasized that the expiration of a term or condition (for conditional obligations) is the basis for the right to judicial protection, and the corresponding capacity for coercion is an element of the most protected power and cannot be detached from the right itself. This state of subjective law, which as a result of its violation has become coercive, was called the right to sue in the material sense ${ }^{11}$. In this case, the content of the subjective right itself as a result of its violation does not change in any way both in terms of scope of powers and in terms of duration. The law does not change, it simply acquires a new property - to be realized by judicial coercion. From the outside, this state of subjective law, according to scholars who defend this concept, is personified in a new legal relationship of the protective type, the content of which is the forced implementation of civil law against the will of the obligated person. The same subjects remain involved in this

11 Чечот Д.М. Субъективное право и формы его защиты. Ленинград : Изд-во Ленингр. ун-та, 1968. С. 25-26. 
relationship. Thus, despite the rather ambiguous opinions expressed in the literature about the essence of the substantive right to sue in the context of its relationship with subjective civil law, the definition of subjective law as a measure of possible conduct of an entitled person (right to own actions), the right to demand specific behavior from other persons and to protect the right in case of its violation.

After the violation of the subjective right, it acquires a claim and can be enforced. The stay of civil law in the state of the right to sue in the material sense is limited by the statute of limitations. These terms do not relate to the duration of the substantive law itself or to the period during which a person may institute legal proceedings, they only determine the period of time during which the subjective right acquires coercive property. However, the loss of the subjective right of his claim security (for example, after the expiration of the statute of limitations or after the plaintiff's waiver of the claim, which entails the termination of proceedings and the subsequent impossibility of going to court with the same claim) does not mean termination of civil law. Thus, historically, most civil researchers have held the view that the possibility of judicial protection of the violated right is an integral feature of the law itself, its intrinsic nature ${ }^{12}$. The differences between them within the commented concept of belonging to any subjective right property to coercion was only that some authors considered such a property inherent in the subjective right from the time of its emergence, noting that it acquires the ability to realize from at the time of the offense, others argued that it is the subjective right with the offense passes to the state of claim, transforming and gaining the ability to defend. In other words, the opinions of its supporters differ on the question of when such a property arises.

Thus, B.B. Cherepakhin believes that the ability to enforce is an integral element of subjective law from the time of its emergence ${ }^{13}$. Instead, according to Russian pre-revolutionary civilians, the right to sue does not manifest itself as positive, as long as the subjective right is exercised unhindered ${ }^{14}$. Slightly modified, but essentially with the same internal content, the construction of subjective law was built by researchers of this issue at the beginning of the Soviet period. In particular, MP Ring also argues that the ability of the subjective right to protection arises only after the violation ${ }^{15}$. In the end, the latter point of view proved to be more convincing and productive. Thus, the dominant theory has been that such a property does not arise automatically in civil law from the time of its

\footnotetext{
${ }_{12}^{12}$ Мейер Д.И. Русское гражданское право: в 2 ч. Москва : Статут, 2000. С. 323.

13 Черепахин Б.Б. Труды по гражданскому праву / научн. ред.. С.С. Алексеев. Москва : Статут, 2001. С. 282.

14 Энгельман И.Е. О давности по русскому гражданскому праву. Историко-догматическое исследование. Москва : Статут, 2003. С. 401.

15 Ринг М.П. Исковая давность и ее значение в укреплении хозяйственного расчета. Вопросы советского гражданского права. 1955. С. 73.
} 
existence, but is acquired only in the case of other persons committing acts that violate the regulatory obligation. It is after the violation of a subjective right or non-fulfillment of one's duty (which, in the end, is the same violation of the right) that it becomes intense ${ }^{16}$, ie receives coercive force.

It should be noted that even in Soviet times, attempts were made to move away from the classical understanding of the right to sue as an element of the most subjective right. Yes, I.M. Bolotnikov pointed out that in subjective law there is only the possibility of the right to sue, which either terminates with the termination of the legal relationship, or becomes the right to sue in case of violation. The author defined the right to sue as the right to enforce the claims of a person arising from the violation of subjective rights ${ }^{17}$. However, the author failed to take the next logical step regarding the fact that the implementation of the protection and legal requirement provides protection of the violated protected right. Eventually, this led him to the then traditional conclusion that the subjective right had been violated and the right to sue in the material sense.

\section{Modern view on the legal mediation of regulatory and security relations}

As already noted, Soviet scientists, such as M.A. Gurvich, S.M. Bratus, M.M. Agarkov, O.S. Ioffe, B.B. Cherepakhin, adhered to the paradigm, which postulated that after the violation of material the legal relationship is transformed, the subjective right becomes a state of maturity of the claim (claim), takes the form of a substantive right to sue. The basic principles of this theory were expressed most fully MA Hurwich: in the case of an offense, the subjective substantive law passes into the so-called "tense" state, ie the stage of the right to sue, the subjective right acquires the ability to enforce with the help of a state jurisdiction, and this is the essence of protection of the violated substantive rights. Unfortunately, we must state that today most scientists share this approach to one degree or another. Despite the fact that in modern civilization other, more progressive models of civil law interactions have been developed, which arise in case of violation of regulatory law ${ }^{18}$, the legal concept, although in a slightly modified form, has a significant number of supporters today.

So V.M. Protasov proposes to consider the rights and obligations arising from the offense as an anomalous stage in the development of the regulatory relationship. According to the scientist, these rights and responsibilities are

\footnotetext{
${ }^{16}$ Гурвич М.А. Прво на иск / отв. ред. : Клейнман А.Ф. Москва - Ленинград : Изд-во АН СССР, 1949. С. 142.

17 Болотников И.М. Проблемы исковой давности в советском гражданском праве : автореф. дис. ...... канд. юрид. наук. Ленинград, 1964. С. 6.

${ }^{18}$ Крашенинников Е.А. К учению об исковой давности. Материально-правовые и процессуальные средства охраны и защиты прав и интересов хозяйствующих субъектов. Калинин, 1987. С. 54-56.
} 
not part of the new relationship, because its participants are still the same subjects. However, the author still rejects the possibility of using coercion within the regulatory relationship, pointing out that this relationship does not mediate measures of state coercion, there is no place for law enforcement and it can be implemented only on a voluntary basis ${ }^{19}$. P.P. Kolesov adheres to a similar position: the method of protection is regulatory in nature, because it is always associated with a material claim, which is the subject of the claim and follows from the substantive legal relationship ${ }^{20}$. L. Litovchenko defends the thesis of reconciling the old concept with the new vision of the subjective right to protection as a separate protective legal relationship ${ }^{21}$. In our opinion, all these are half-steps, modern civilization has already firmly developed new paradigms, according to which the regulatory and protective state of legal relations differ significantly, and the determining factor is the temporal properties of substantive law: in the first case it has no ability to enforce, then as in the second - it is an integral part of the order of its implementation.

We believe that the concept that the protective property of subjective law is an integral part of it from the time of its origin is outdated and inadequate. It cannot cover the legal nature of a substantive claim that arises and is realized after a violation of a subjective right. And not only because this approach in its essence is not consistent with the real state of modern material interactions. The fact is that researchers make the mistake of equating the protective capacity of a subjective right exclusively with a claim (substantive right to sue). Meanwhile, the obvious differences between the legal essence of regulatory and protective relations are a manifestation of the practical application of the theoretical idea of the main functions of civil law - regulatory and protective. The latter is personified, including through the exercise of the substantive right to sue, which occurs within a certain period set for this - the statute of limitations. But today it has been convincingly proved that the protection of the violated subjective right takes place not only in a lawsuit, it can also be carried out in a non-judicial manner. Thus, the ways to protect subjective rights include, for example, the use of certain mechanisms of self-defense, the so-called measures of operational influence ${ }^{22}$ and so on. Thus, at the present stage can no longer adequately explain the essence of material relations openly outdated theory

19 Протасов В.Н. Основы общеправовой процессуальной теории. Москва : Юрид. лит., 1991. С. 76-77.

20 Колесов П.П. Процессуальные средства защиты права : монография. НовГУ имени Ярослава Мудрого. Великий Новгород, 2004. С. 24.

${ }^{21}$ Литовченко Л. Право на захист цивільних прав та інтересів. Підприємництво, господарство і право. 2014. № 54. С. 22-23.

${ }^{22}$ Грибанов. В.П. Осуществление и защита гражданских прав. Москва : Статут, 2000. C. 38 . 
of the universality of the legal relationship, even taking into account the traditional provision of its change in the case of an offense.

For the first time the classification of civil legal relations as regulatory and protective was carried out by the well-known pre-revolutionary lawyer S.A. Muromtsev. However, he did not use modern terminology in his research, but called the relationship, respectively, protective and protected. $\mathrm{He}$, in particular, emphasized that when an offense is committed, then the existing relationship is joined by a new legal relationship of the subject to the offender ${ }^{23}$. The name "protective" for these relationships was introduced into civil circulation by N.G. Alexandrov. He pointed out that the violation of the rule of law leads to a special (law enforcement) relationship between the offender and the competent authority of the state, which is aimed at applying a certain sanction to the offender in case of confirmation of illegality ${ }^{24}$. In the Soviet period, the concept of the division of legal relations into regulatory and protective on the basis of their origin was supported by a number of scholars. However, dividing the essence of these relations, these researchers first considered the protective relationship that arose in case of violation of regulatory law, within the concept of procedural right to sue. To some extent, this approach is inherent in some modern scientists. Thus, G.L. Osokina emphasizes that the subjective right to sue is an element of the protection-claim procedural relationship, because this right corresponds to the duty of the court as a jurisdictional body of the state ${ }^{25}$.

But later, with the development of theoretical developments on the essence of the protective legal relationship and its element - the claim, more and more researchers began to lean towards the substantive interpretation of such relationships. What is the key factor that separates regulatory and protective legal relations. The analysis of doctrinal research allows us to conclude that the legal definition of the positive actions of the holder of subjective law and the requirement of proper active behavior from obligated persons as components of the protection of subjective law is practically controversial today. By and large, the main difference in the views of scholars concerns the question of the composition of the subjective right of its protective properties. Therefore, we must find out whether the protection and legal authority is a certain state of the violated civil law, or whether it is a separate subjective right of its holder. Because, as we have already mentioned, the concept according to which the power to use state coercion to protect the violated subjective right is part of the same right, and not a

${ }^{23}$ Муромцев С.А. Определение и основное разделение права. Санкт-Петербург : Изд. Дом Санкт-Петербургского государственного университета, 2004. С. 78, 84.

Александров Н.Г. Законность и правоотношения в советском обществе. Москва : Госюриздат, 1955. С. 91-92.

25 Осокина Г.Л. Курс гражданского судопроизводства России. Общая часть : учебное пособие. Томск : Изд-во Томского университету, 2002. С. 467-468. 
separate substantive power of the person, and today continues to have many supporters.

However, the widespread thesis that the protective capacity is part of the regulatory subjective right, and the protection of the latter is through its enforcement, in modern science causes a significant number of objections ${ }^{26}$. And this is quite natural. After all, it is obvious that the requirements of a protective nature, which appear in the commissioner from the time of the violation of his substantive law, have other temporal characteristics, different from the regulatory requirements. It is true that a violated (unregulated) requirement, such as the performance of an obligation in kind, may also be reproduced in a claim, but as such it is only one of several different claims, not the only one. It is the regulatory civil law relationship that is formed and implemented under the condition of proper exercise of its right by the entitled person and appropriate due performance of its duty by the obligated person. The right of the creditor arising from such a regulatory obligation is not endowed with the property of enforcement, because it is not accompanied by the so-called grounds for action - in particular not violated by other persons. When there is a violation of civil law, it acquires the ability to be protected. And such protection cannot be covered by the mechanisms inherent in the legal organization of regulatory relations, even taking into account the above transformations of subjective law.

\section{A new concept regarding the development and duration of the protective relationship in violation of subjective law}

Given the obvious imperfections and ineffectiveness of the above legal paradigm, the development of a qualitatively new doctrine on the nature and belonging of the subjective right of a person - the holder of the violated civil right - to protection has become an objectively necessary phenomenon. Therefore, it is quite logical that another scientific concept, radically different from the above, was developed in the doctrine. Its essence lies in the basic provision, according to which the right to judicial protection (claim) is an independent material power, which is realized within the protection-legal relationship ${ }^{27}$. Of course, such a subjective right cannot be an integral part of the regulatory subjective substantive law.

This position is consistently held by a number of well-known Ukrainian civilians. For example, N.S. Kuznetsova, determining the independence of the protective right of a person, compares it with other subjective rights that can be exercised by the bearers at their discretion on the basis of dispositiveness and free will, since the legislator has established a general civil rights regime.

26 Приватноправові механізми здійснення та захисту суб'єктивних прав фізичних та юридичних осіб / за ред. В.Л. Яроцького. Харків : Юрайт, 2013. С. 201.

27 Крашенинников Е.А. Структура субъективного права и права на защиту. Проблема защиты субъективных прав и советское гражданское судопроизводство . Ярославль, 1979. Вып. 4. С. 76-77. 
regulation ${ }^{28}$. Z.V. Romovska defends the thesis about the independence of the right to protection and its non-connection with a specific protected right ${ }^{29}$. This theory is quite sound from a methodological point of view and deserves attention. It currently most fully meets the requirements that the legal justification of specific relationships should not only be adequate to the needs of social development, but also create a certain space and incentive for the further gradual development of regulated relations.

Indeed, a careful analysis of the issue shows that there are significant differences between regulatory and protection law. First of all, they concern the content of each of these subjective powers. Regulatory law covers the actions of the holder to exercise the powers inherent in the subjective law, or by independent action, or by requiring certain behavior from the counterparty on a voluntary basis. Instead, the content of the protection law includes the power to terminate the offense and eliminate its negative consequences $^{30}$. The exercise of such authority occurs only through the commission of a certain act by the debtor, and such acts are both voluntary and carried out by state coercion. It should also be noted that the scope and direction of powers under regulatory and protective legal relations do not coincide. If we examine in more detail the nature and legal nature of the actual relations that take place in the commented area, we will certainly see a clear inconsistency of the above superstructure with the real state of affairs. It cannot be accepted that the possibility to seek protection of the infringed right in court, along with the authority to conduct oneself and to demand appropriate conduct from the debtor, is part of any subjective right. In fact, such a possibility is inherent only in the protective substantive law, and it actually coincides with the authority of the person entitled to take active action through the implementation of the claim. Therefore, the opinion according to which the right to protection is an independent subjective right seems quite convincing and balanced.

From the doctrinal point of view, this thesis found its expression in the legal mechanism, according to which in violation of the law there is a new legal relationship of protective content ${ }^{31}$. Such a protective relationship arises as a result of violation or challenge of regulatory law, and the essence of the substantive claim addressed to the obligated person is to eliminate the offense and its consequences, to restore the right, and so on. The protection

28 Цивільний кодекс України: науково-практичний коментар / за ред. О.В. Дзери, Н.С. Кузнєцової, В.В. Луця. Київ, 2004. С. 30.

${ }_{29}$ Ромовська 3.В. Українське цивільне право. Загальна частина. Київ : Атіка, 2005. С. 482.

${ }_{30}$ Елисейкин П.Ф. Охранительные нормы (понятие, виды, структура). Защчита субъективных прав и советское гражданское судопроизводство / под ред. П.Ф. Елисейкина. Ярославль, 1977. С. 26.

31 Бутнев В.В. Понятие механизма защиты субъективных гражданских прав. Механизм защиты субъективных гражданских прав : сборник научных трудов. Ярославль : Яросл. ГУ, 1990. С. 11-12. 
requirement is not necessarily implemented in court, as evidenced by the content of Chapter 3 of the Civil Code of Ukraine. In particular, the subject of the violated right may in some cases protect it administratively or notarially, apply self-defense measures, etc. But in any case, for extrajudicial or judicial implementation, the requirement must exist from the time of the violation. In view of this, it is impossible to agree with the opinion of researchers who link the emergence of a protective legal relationship with the moment a person goes to court.

Indeed, if we agree with the thesis that the protection of the violated subjective right occurs through its enforcement, it is impossible to legally substantiate the powers of a person to protect the right in certain ways that do not coincide with the content of the violated right. From the point of view of the commented doctrine it is possible to explain protection, say, the right to payment of means by their judicial recovery from the debtor which could be qualified as compulsory performance of the duty in kind. However, from the specified offense the commissioner can have other requirements, for example, collection of a penalty, compensation of losses, termination of the contract, etc. These powers of the creditor are also aimed at protecting the violated subjective right, but in their content they do not coincide with it. Therefore, the satisfaction of such claims in court cannot be characterized as the enforcement of the violated right, since such possibilities were not inherent in the law itself: the creditor did not have subjective rights of a similar content in the intact state. So, we get that these protective powers arose only from the time of the offense or after it (say, fines, damages occur later, their volume usually increases with time from the term of the violation, so the statute of limitations for each claim arises each time after the next violation, for example, infliction of the next damage) and have independent in comparison with regulatory law character as they do not follow from it. This clearly confirms the thesis that, in fact, the regulatory relationship in the event of its violation is terminated, and not become a protective or an element of the latter - harassment.

Thus, a broad understanding of the concept of "protection of civil rights" can be considered quite logical and justified in civilization. It includes the whole set of measures of organizational, economic, political nature, etc., aimed at creating conditions for the exercise of subjective law, in civilization, a narrower understanding of the concept of "protection". These are measures prescribed by law aimed at restoring or stopping the violation of civil rights. In fact, they constitute the content of the civil law definition of the protection of subjective rights. The right to protection can be formulated as the right holder has the opportunity to apply law enforcement measures to restore his violated right. It is realized through the exercise (often compulsorily) of the protective and legal capacity of the right to exercise in case of violation. Therefore, the property of enforcement is not inherent in the regulatory but in the protection obligation. Indeed, after a 
breach of a regulatory obligation, there can be no question of its continued existence. There is no longer a relationship that would mediate the normal, lawful development of subjective law and the corresponding legal obligation. But there is a protective obligation, and it is precisely its element - the protective subjective right will continue after the violation and can be properly implemented, including with the help of a state jurisdiction - the court. It is the duration of such a relationship in the form of a claim is referred to in the relevant chapter of the Civil Code, which regulates the issue of the application of the statute of limitations as a time for enforcement of the violated right. The substantive law inherent in the believer does not depend on the expiration of the statute of limitations, although after such an expiration it loses its coercive property.

\section{CONCLUSIONS}

From the above we can draw certain conclusions. Regulatory is a legal relationship under which the normal substantive and legal interaction of its participants. The authority due to the authorized person is exercised by him / herself independently or by performing the necessary actions by the obligated subject. When there is a violation of the substantive rights of a participant in civil relations, on the basis of non-compliance with the conditions of the regulatory relationship there is a security, the content of which will be the realization of the possibility of legal protection of the creditor's rights. In the case of violation of subjective law, there is a relationship that has a protective and legal nature. It includes the material claim of the right holder to the infringer and the corresponding obligation of the latter. Such relations arise where and to the extent that there is a need and the possibility provided by law to protect the violated substantive law. In case of violation of the normal order of conduct by the parties, the relationship between them is of a completely different nature, they will be aimed at eliminating the violation, termination of improper performance of duties, compensation, etc., including by applying measures to the violator coercion.

At the same time, it would be incorrect to reduce the specified protection and legal material requirement only to the claim of the commissioner. The latter is not obliged to defend his right only in court. Other non-judicial means of protection also occur through the implementation of the protection requirement of the person arising from the offense and is the authority of the protection relationship. This out-of-court claim is not covered by the statute of limitations, it is usually not subject to limitation and exists for the duration of the protection right itself. As for the content of the protective non-judicial claim, it may be the same as the claim. When a protective legal relationship arises, the possibility of applying coercive measures becomes concrete, real, and this is the essence of the creditor's right to sue in the material sense. Thus, we can conclude that the protective relationship arises only when there is a 
violation of the subjective substantive right of the person and they characterize the ability of the subjective right to be protected.

\section{SUMMARY}

The article is devoted to the scientific study of the topical issue of the essential features of the development and implementation of the subjective powers of the right holder and the corresponding responsibilities of the debtor in regulatory and protective legal relations. The historical analysis of the formation of the doctrine of the different nature of these relations is carried out, different civilistic approaches to the key question are studied: what happens to the subjective right of the bearer in case of its violation. The study of conceptual views, describes the gradual change of scientific vision of the legal relationship from a universal phenomenon that can be transformed from an intact state to a disturbed, to the latest concept of the division of material relations into regulatory and protective. The author critically evaluates the theory that has dominated for many years about the transition of law as a result of its violation into the so-called "tense' state. The thesis that after the deadline, the unrealized right becomes a claim and the implementation of the statute of limitations begins on the relevant requirements is not consistent with modern legal concepts. According to the author, from the moment of violation the regulatory right ceases, instead a new subjective right arises - protective, which from the time of its appearance has a protective coercive property. The question of the essence and temporal manifestations of such an objectively existing phenomenon as the protection and legal relationship has been studied. It is concluded that it is within the framework of the latter, which arises from the moment of the offense, that the protection of the protective property of subjective law is possible. It is proved that the right to sue as a realization of the protective ability belongs only to the participant of the protective interaction. Conversely, a creditor's right under a regulatory obligation is not enforced.

\section{REFERENCES}

1. Харитонов С.О. Класифікація цивільних правовідносин: спроба новацій у підходах. Наукові прайі Одеської національної юридичної академії. С. 136-143.

2. Цивільне право України / за ред. О.В. Дзери, Н.С. Кузнєцової. Київ : Юрінком Інтер, 2002. 720 c.

3. Осокина Г.Л. Право на защиту в исковом судопроизводстве (право на иск). Томск : Изд-во Том. ун-та, 1990. 160 с.

4. Гамбаров Ю.С. Гражданское право. Москва : АО «Центр ЮрИнфоР», 2003. 816 с.

5. Гурвич. М.А. Право на иск / отв. ред. : Клейнман А.Ф. Москва Ленинград : Изд-во АН СССР, 1949. 216 с. 
6. Грибанов В.П. Право на защиту как одно из правомочий субъективного гражданского права. Вестник МГУ. Серия XII. Право. 1968. № 3. C. 10-23.

7. Unger, J. System des jsterreichischen allgemeinen Privatrechts / Bd. I, 2 Aulf. Leipzig, 1892. Bd. 2. 456 S.

8. Иоффе О.С. Советское гражданское право. Москва : Юрид. лит., 1967. $494 \mathrm{c}$.

9. Новицкий И.Б. Сделки. Исковая давность. Москва : Госюриздат, 1954. $274 \mathrm{c}$.

10. Чечот Д.М. Субъективное право и формы его защиты. Ленинград : Изд-во Ленингр. ун-та, 1968. 72 с.

11. Мейер Д.И. Русское гражданское право : в 2 ч. Москва : Статут, $2000.831 \mathrm{c}$.

12. Черепахин Б.Б. Труды по гражданскому праву / научн. ред. С.С. Алексеев. Москва : Статут, 2001. 479 с.

13. Энгельман И.Е. О давности по русскому гражданскому праву. Историко-дог-матическое исследование. Москва : Статут, 2003. 511 с.

14. Ринг М.П. Исковая давность и ее значение в укреплении хозяйственного расчета. Вопросы советского гражданского права. 1955. C. 64-93.

15. Болотников И.М. Проблемы исковой давности в советском гражданском праве : автореф. дис. ... канд. юрид. наук. Ленинград, 1964. $16 \mathrm{c}$.

16. Крашенинников Е.А. К учению об исковой давности. Материально-правовые и процессуальные средства охраны и защиты прав и интересов хозяйствующих субъектов. Калинин, 1987. С. 53-59.

17. Протасов В.Н. Основы общеправовой процессуальной теории. Москва : Юрид. лит., 1991. 144 с.

18. Колесов П.П. Процессуальные средства защиты права : монография. НовГУ имени Ярослава Мудрого. Великий Новгород, 2004. $220 \mathrm{c}$.

19. Литовченко Л. Право на захист цивільних прав та інтересів. Підприємництво, господарство і право. 2014. № 54. С. 20-24.

20.Грибанов. В.П. Осуществление и защита гражданських прав. Москва : Статут, 2000. $411 \mathrm{c.}$

21. Муромцев С.А. Определение и основное разделение права. Санкт-Петербург : Изд. Дом Санкт-Петербургского государственного университета, 2004. $224 \mathrm{c}$.

22. Александров Н.Г. Законность и правоотношения в советском обществе. Москва : Госюриздат, 1955. $176 \mathrm{c.}$

23. Осокина Г.Л. Курс гражданского судопроизводства России. Общая часть : учебное пособие. Томск : Изд-во Томского университету, 2002. $616 \mathrm{c}$. 
24. Приватноправові механізми здійснення та захисту суб'єктивних прав фізичних та юридичних осіб / за ред. В.Л. Яроцького. Харків : Юрайт, 2013. 272 с.

25. Крашенинников Е.А. Структура субъективного права и права на защиту. Проблема защиты субъективных прав $u$ советское гражданское судопроизводство. 1979. Вып. 4. С. 73-82.

26. Цивільний кодекс України: науково-практичний коментар / за ред. О.В. Дзери, Н.С. Кузнєцової, В.В. Луця. Київ, 2004. 928 с.

27. Ромовська 3.В. Українське цивільне право. Загальна частина. Київ : Атіка, 2005. 560 с.

28. Елисейкин П. Ф. Охранительные нормы (понятие, виды, структура). Защита субъективных прав и советское гражданское судопроизводство / под ред. П.Ф. Елисейкина. Ярославль, 1977. 148 с.

29. Бутнев В.В. Понятие механизма защиты субъективных гражданских прав. Механизм защиты субъективных гражданских прав : сборник научных трудов. Ярославль : Яросл. ГУ, 1990. 164 с.

\section{Information about the author:} Guyvan P. D., Ph. D. in Law, Honored Lawyer of Ukraine, Professor Poltava Business Institute of Academician Yuriy Bugay International

Scientific and Technical University 7, Sinna str., Poltava, 36000, Ukraine 